Article

\title{
A Case Study of BIM Implementation in Rail Track Rehabilitation
}

\author{
José Neves ${ }^{1, * \mathbb{D}}$, Zita Sampaio ${ }^{1}$ and Manuel Vilela ${ }^{2}$ \\ 1 CERIS-Civil Engineering Research and Innovation for Sustainability, Department of Civil Engineering, \\ Architecture and Georesources, Instituto Superior Técnico, Universidade de Lisboa, Avenida Rovisco Pais, \\ 1049-001 Lisboa, Portugal; zita.sampaio@tecnico.ulisboa.pt \\ 2 Instituto Superior Técnico, Universidade de Lisboa, Avenida Rovisco Pais, 1049-001 Lisboa, Portugal; \\ manuel_vilela_@hotmail.com \\ * Correspondence: jose.manuel.neves@tecnico.ulisboa.pt; Tel.: +351-918-639-745
}

Received: 30 December 2018; Accepted: 15 February 2019; Published: 19 February 2019

check for updates

\begin{abstract}
Building Information Modeling (BIM) is an Industry 4.0 methodology that is increasingly used in the domain of Architecture, Engineering, and Construction (AEC). BIM emerges as a new methodology, one that is more collaborative and based on parametric three-Dimensional (3D) models, centralizing different types of information of a geometric, physical, and economic nature. The purpose of this paper is to analyze the application of the BIM methodology to a rail track rehabilitation case study using a geotextile and geogrid in the ballast layer base. The creation of the 3D and 4D BIM models was performed using various BIM-based tools, which made it possible to achieve the spatial and parametric representation of the rail track and the simulation of the main construction tasks. A new BIM object pertaining to the rail track was created. This paper describes the procedures applied in achieving the BIM models, the limitations involved, and the interoperability between the BIM tools. Additionally, the potential for information extraction with respect to the infrastructure design, construction, and operation, e.g., planning and scheduling, quantities, graphic outputs, and track geometry quality, was demonstrated. It was concluded that the BIM methodology was viable and could be implemented with benefits, despite certain difficulties and limitations, which emphasize the need for further developments.
\end{abstract}

Keywords: BIM; railway; rehabilitation; geogrid; geotextile

\section{Introduction}

In the context of Industry 4.0, Building Information Modeling (BIM) is a powerful methodology, which has been implemented with great success in the domain of Architecture, Engineering, and Construction (AEC) [1-3]. Indeed, the construction industry has been working intensively on the implementation of the BIM methodology in several segments [4-6]. BIM is a collaborative work concept, strongly based on technological advances in computation. BIM tools enable the development of building projects during their lifecycle, including the design, construction, maintenance, management, and demolition phases. However, it is as yet hardly ever used in the transport infrastructure sector (roads, railways, bridges, tunnels, airports, and ports) [7-12]. It is important to develop the BIM-related software for the field of transport infrastructures and to encourage the implementation of this methodology in companies in the sector [13-15]. Taking into consideration that the global railway industry market is showing solid growth [16], there will be unquestionable interest in the application of BIM in the particular case of railway infrastructure [13,16-29].

Although only a few case studies have been reported in the literature, there is growing interest in the applicability of BIM to the transport infrastructure sector. Two cases of road projects were found 
in Australia and Shanghai [30]. These cases describe: the development of the project and simulation planned with a certain number of BIM tools; the elaboration of a network-based interface for the BIM model; integration of BIM with GIS; the tracking and updating of the development of the BIM model; the integration of BIM with a laser scanning device; and the printing of the 3D model.

As argued by Bensalah et al. [9,31], the advantages and benefits of the integration of BIM in rail projects are considerable, for example: cost control; decision-making support; reduction in design errors; detection of interface problems; improvement of visual perception; prefabrication support; maintenance planning support; and infrastructure management. Shin et al. [32] have also pointed out the financial benefits that BIM can bring to a real project.

However, interoperability remains a major problem in horizontal infrastructures due to the lack of standardized data. BuildingSMART, an international organization that develops and implements BIM standards, has already commenced work on creating data standards for roads, railways, bridges, and tunnels, which can improve interoperability and integration, based on different objects, alignment, and GIS models $[5,25,32,33]$.

Considering the analyses of the interoperability capacity between software and the universal data format of data, Industry Foundation Classes (IFC) became essential. The IFC standard was created to allow for the sharing of complete and accurate models among various stakeholders, regardless of the applications they use, to ensure efficient exchange of information throughout the process. Recently, there have been significant advances focused on the creation of ifcObjects [34] concerning rail objects (e.g., track, subgrade, tunnels, or viaducts). In the present study, the 3D modeler software, most frequently used in infrastructures, namely Civil $3 \mathrm{D} \circledast$ and InfraWorks ${ }^{\circledR}$, was adopted in the process of modeling the considered study case. Both models were later transposed to Revit ${ }^{\circ}$, using the respective ifc model. However, it was found that the result of the transposition of both ifc models to Revit was seriously inefficient, and as such, a complete BIM model was created within Revit. In addition the interoperability between Civil $3 \mathrm{D} \AA$ and Revit ${ }^{\circledR}$ was also analyzed in terms of the terrain modeling, using also the ifc format. As far as the actual level of BIM implementation in transport infrastructures is concerned $[7,11]$, further demonstrations are desirable in order to stimulate the development of the BIM methodology and its acceptance by the companies involved in planning, design, construction, and maintenance.

The main objective of the proposed study is to analyze the current capacity of BIM tools, when used in the field of railway infrastructure. With this purpose, a case study concerning the rehabilitation of a railway segment was considered, having applied various software, in order to assess the benefits and limitations inherent in the process. The paper describes the three-Dimensional (3D) modeling of the project in two BIM software programs and, additionally, the four-Dimensional (4D) modeling using another BIM viewer. Tests for interoperability were carried out before the use of the various BIM-based tools. The capacity for extracting information that could be used for infrastructure design, construction, and maintenance was also explored. The findings showed that there is still a huge technological inability in this field.

\section{Research Methodology}

\subsection{Case Study Description}

A $35 \mathrm{~km}$-long section of railway infrastructure in Portugal was rehabilitated in 2016. This section was characterized by intense and mixed rail traffic (passengers and cargo). The rail track ballast in this section was renewed using a combination of a composite of triaxial geogrid and non-woven geotextile in the base. In general, geosynthetics find application in a range of functions in the rehabilitation of existing rail tracks: separation, reinforcement, drainage, and filtration. In this case study, the application of the geotextile had the function of separation and filtration, and the geogrid served to stabilize the ballast layer in order to reduce the lateral movements of the ballast particles. Figure 1 presents a cross-section of the rehabilitated rail track, indicating the terminology adopted in this paper. 


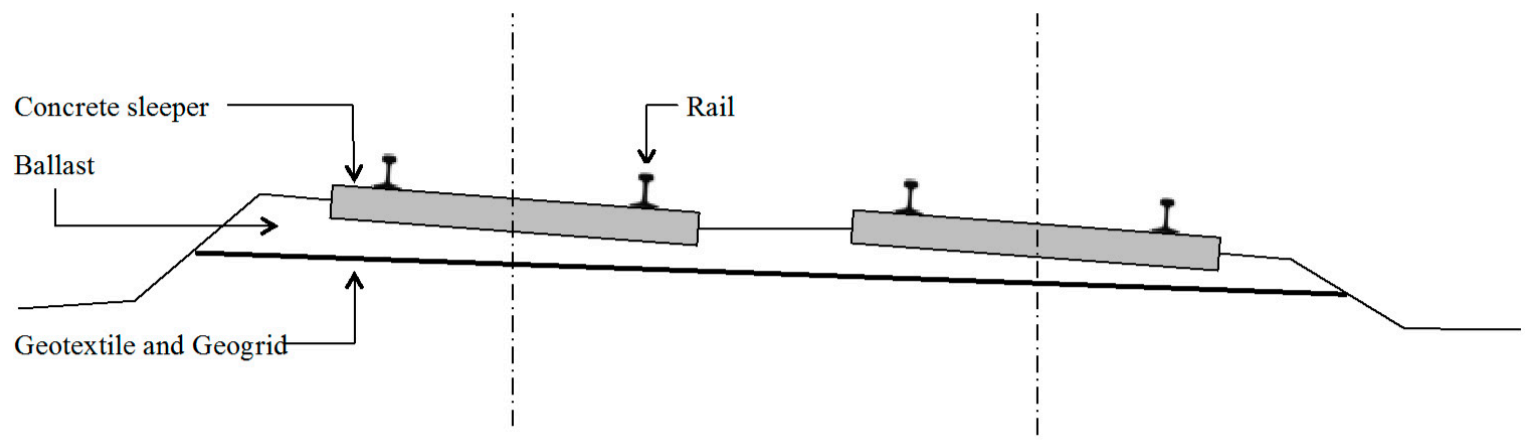

Figure 1. Cross-section of the rehabilitated rail track (adapted from Neves et al. [35]).

Figure 2 shows the main in situ construction phases of the rail track rehabilitation, which were carried out at night:

(a) Replacement of rails, sleepers, and fastenings (Figure 2a).

(b) Removal of ballast (Figure 2b).

(c) Application of a combination of a composite of triaxial geogrid and non-woven geotextile in the base of the ballast layer (Figure 2c).

(d) New ballast tamping (Figure 2d).

After the removal of the contaminated ballast, a track-mounted undercutting machine rolled out the geotextile and geogrid prior to the new ballast being dropped into place over these materials (Figure 2c).

Vilela [36] describes the case study with more details.

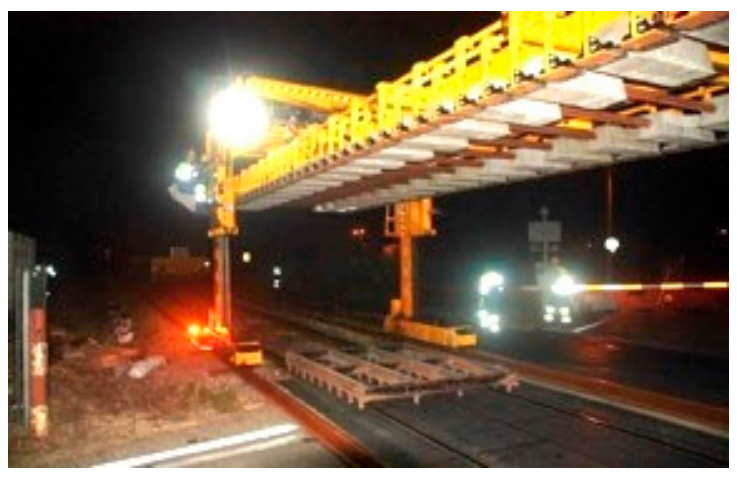

(a)

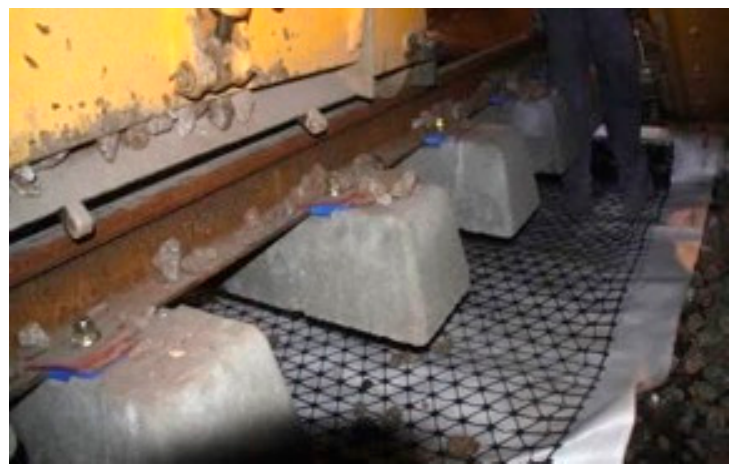

(c)

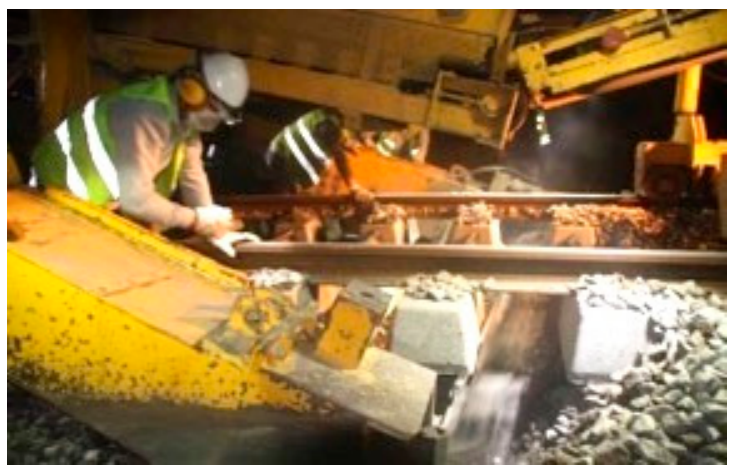

(b)

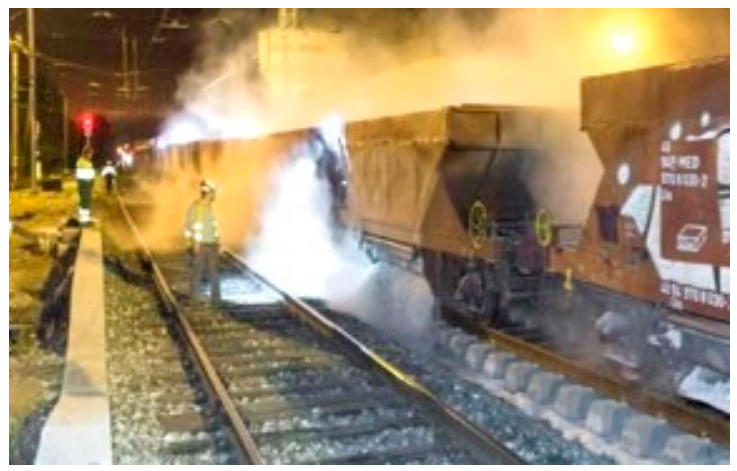

(d)

Figure 2. Construction phases of the railway track rehabilitation: (a) replacement of rails, sleepers, and fastenings; (b) removal of ballast; (c) application of geotextile and geogrid; and (d) new ballast tamping [37]. 


\subsection{BIM Application}

Application of the BIM methodology was demonstrated on a section of the case study track measuring 1787 meters in length. A straight part of the rail track was selected that was considered representative of the case study. Two-Dimensional (2D) representations of the elements of the project are available in paper format or as pdf files [37].

Figure 3 presents a schematic overview of the BIM implementation adopted in this paper: modeling, interoperability, and information extraction. The following Autodesk programs were used: Civil $3 \mathrm{D} \AA$, Revit ${ }^{\circledR}$, and Navisworks ${ }^{\circledR}$. First of all, the geolocation of the case study area and the corresponding natural terrain modeling were carried out using InfraWorks ${ }^{\circledR}$ software. The application of BIM methodology to the case study comprised three phases: (1) creation of the project model (3D model); (2) planning and scheduling of the construction process (4D model); and (3) extraction of diverse model information.

Civil $3 \mathrm{D}{ }^{\circledR}$ software is a common tool used in 3D modeling of transport infrastructures. Revit ${ }^{\circledR}$ software is a well-known BIM-based tool intensively used in the domain of architecture, engineering, and construction. It was also used in the 3D modeling of the railway infrastructure, with a new rail track family being created, including the rails, sleepers, and fastenings. In order to create the four-Dimensional (4D) modeling, incorporating the time element, the geometric model created in Civil $3 D \circledR$ was exported to Navisworks ${ }^{\circledR}$. Using the latter software, the construction process phases for the rail track rehabilitation were recreated. Finally, the extraction of information was demonstrated: planning and scheduling, quantities of materials, graphic outputs, and track geometry quality.
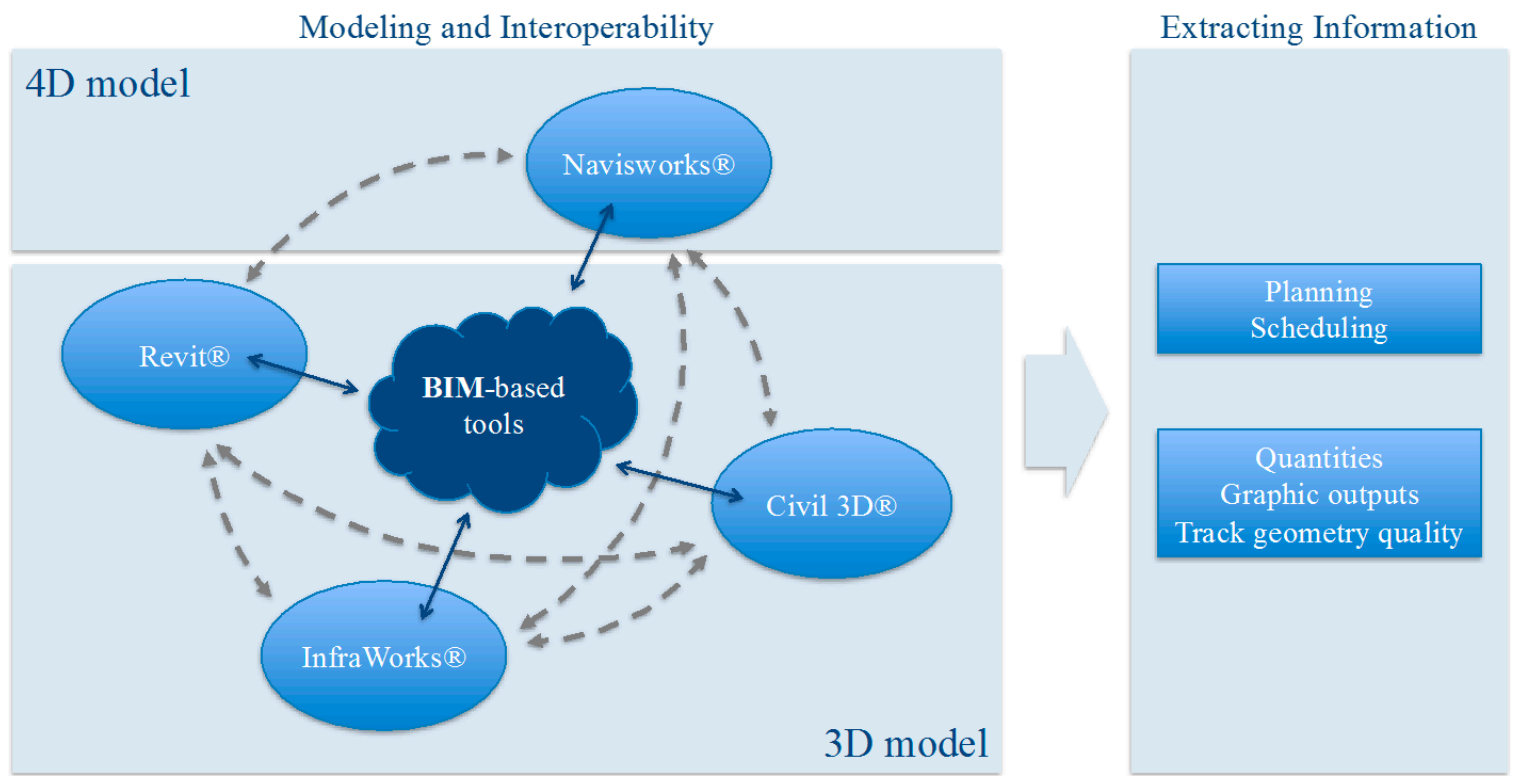

Figure 3. Application of BIM in the case study.

\section{Modeling}

\subsection{D Modeling}

Civil $3 \mathrm{D} ®$ is a program that is commonly used in the geometric design of transport infrastructures. This software was used in the case study to begin the 3D representation of the general railway infrastructure geometry based on the AutoCAD 2D elements of the project: horizontal and vertical alignments and cross-sections.

Prior to this, InfraWorks ${ }^{\circledR}$ provided the most accurate terrain modeling and geolocation of the construction site to be transferred to both Civil $3 \mathrm{D}{ }^{\circledR}$ and Revit ${ }^{\circledR}$. Regarding this objective, another interesting tool is the Digital Terrain Model (DTM), which consists of the three-dimensional 
representation of the terrain based on the digital space mapping of the area. However, it was not possible to explore this tool.

The 3D modeling of the railway infrastructure by Civil 3D® included the track substructure (subgrade and sub-ballast layers) and the superstructure (ballast layer), including also some components of the drainage (pipes) and catenary (vertical poles and cantilevers) systems. After the definition of the horizontal alignment, the longitudinal profile of the terrain was created, and finally, the vertical alignment was established in line with an adequate balance of earthworks and respecting geometric requirements. The two main cross-sections of the rail track were then designed: a section relating to the general railway line and another section corresponding to the particular case of a box culvert. Figure $4 \mathrm{a}$ shows a generic part of the 3D model. In Figure $4 \mathrm{~b}$ is represented a box culvert integrated in the embankment.

Civil $3 \mathrm{D} \circledast$ software is suitable for 3D modeling, as demonstrated once again in this railway infrastructure case study. However, it has certain limitations with regard to the application of the BIM methodology. Revit ${ }^{\circledR}$ software is a well-known BIM-based tool. The interoperability between Civil $3 \mathrm{D} \cap$ and Revit ${ }^{\circledR}$ was analyzed in the case study. However, the complete integration into Revit ${ }^{\circ}$ of the $3 \mathrm{D}$ model created by Civil $3 \mathrm{D} \circledast$ was not successful because most of the elements were not recognized.

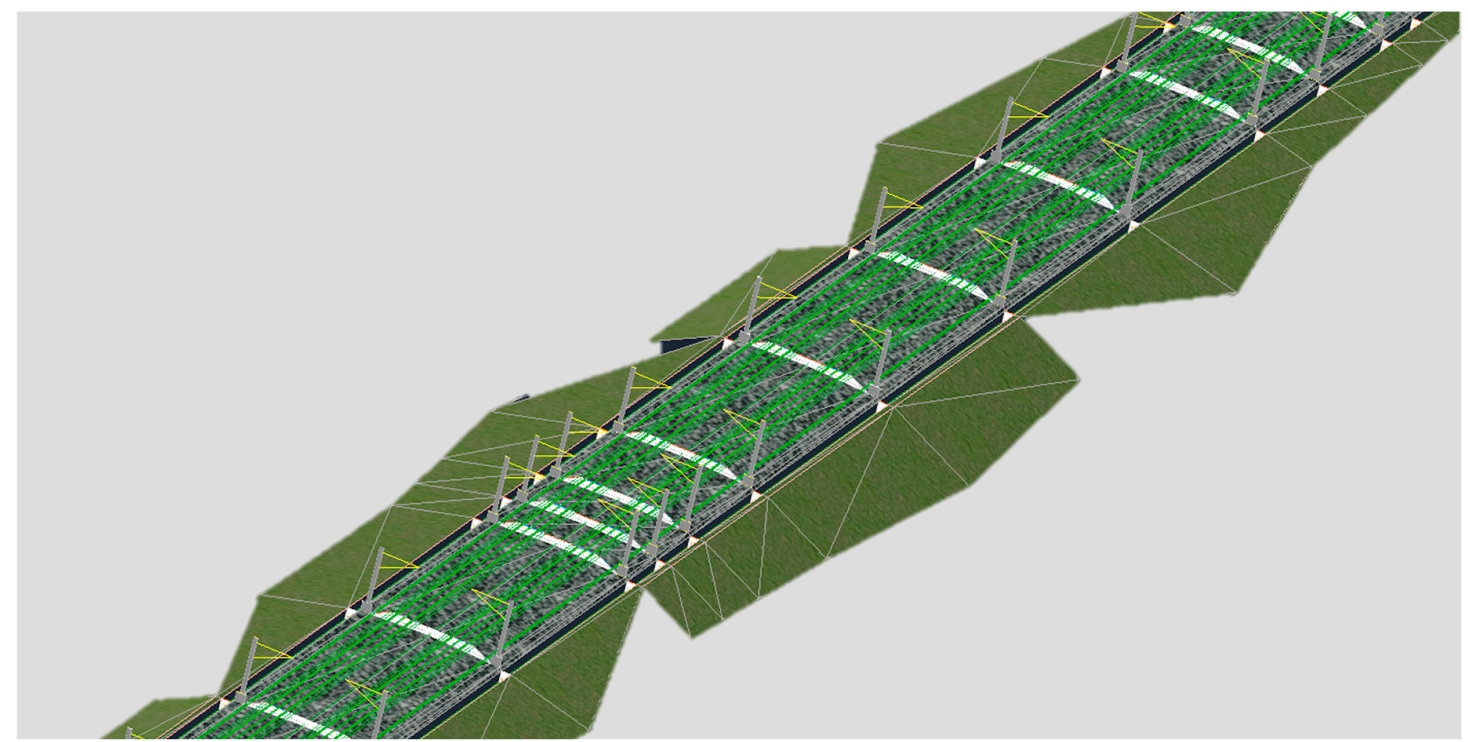

(a)

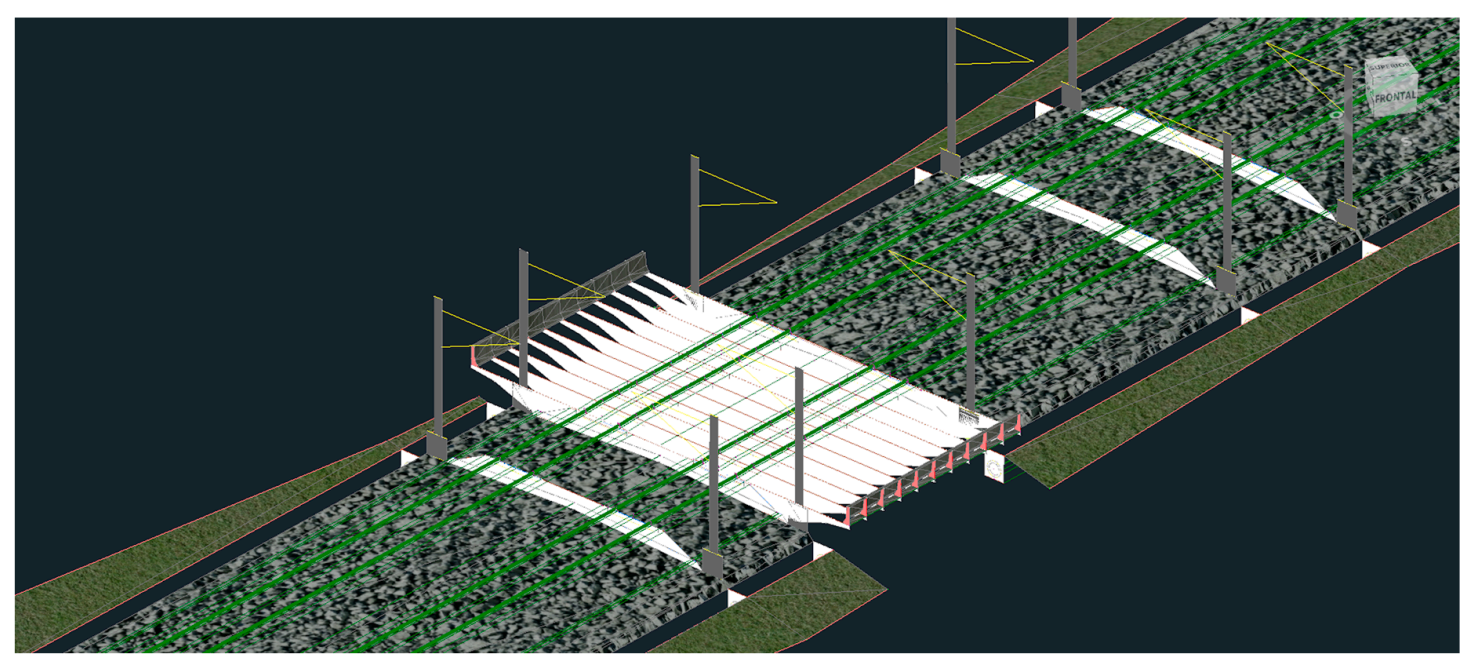

(b)

Figure 4. 3D modeling of the case study: (a) 3D model of the box culvert; and (b) general 3D model. 
Revit $\AA$ has no infrastructure-oriented component, so the possibility of creating new families of objects required for the design of the rail track was explored. It was decided to use Revit $₫$ to generate families of parametric objects related to the railway components, with respect to the geometries and materials used in the case study: rails (UIC 60), bi-block concrete sleepers (VAX LU41 NG), and the corresponding types of fastenings. During this modeling, architecture, structure, and Revit ${ }^{\circledR}$ systems component commands were used.

Based on the integration of two families already existing in the BIM Library related to rail track components-rail, sleeper, and fastening-and using the Railing command, on the Architecture tab and in the Circulation panel, a new Revit ${ }^{\circledR}$ family was created in order to represent the complete rail track: two rails, equidistant sleepers, and corresponding fastenings. In order to ensure the most accurate placement of the rails in the fastenings, some parameters were changed, e.g., Base offset, Top offset, and Distance from previous. The Iberian track gauge of $1668 \mathrm{~mm}$ was adopted for this family. Figure 5 represents the 3D model of the rail track family created in Revit ${ }^{\circledR}$.

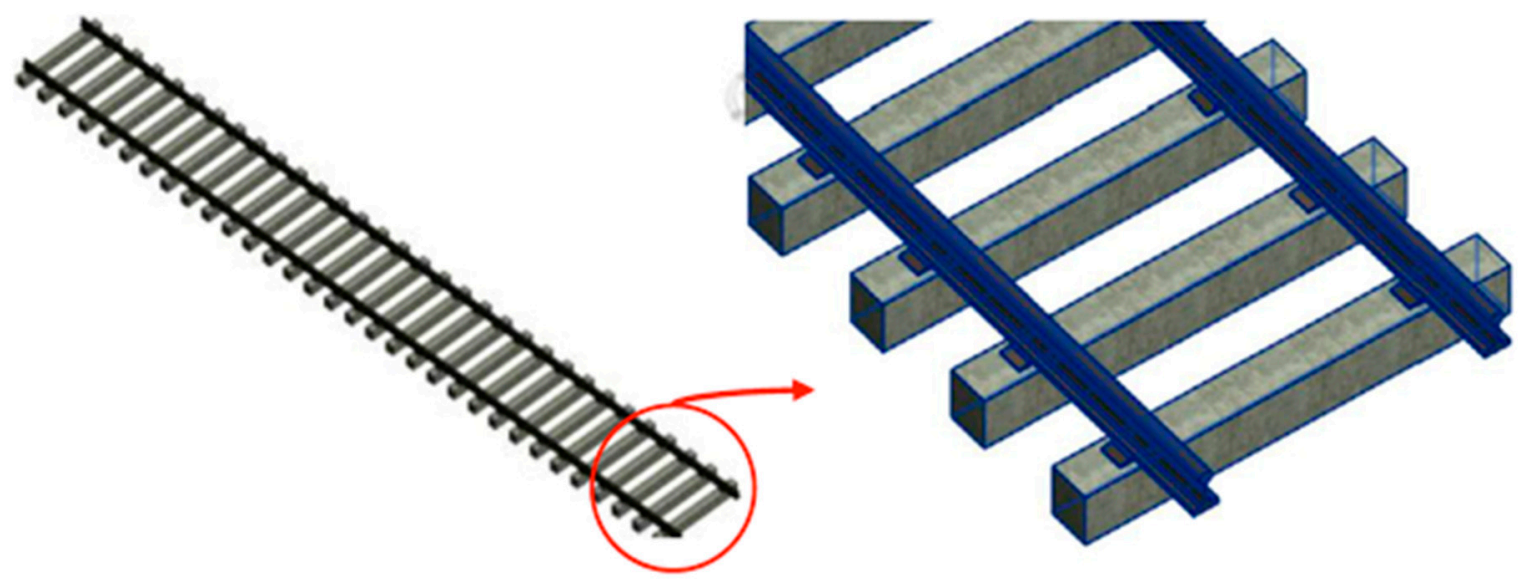

Figure 5. 3D model of the rail track family created in Revit ${ }^{\circ}$

The subgrade, sub-ballast, and ballast layers completed the 3D model of the basic rail track infrastructure and superstructure components. These elements were created through the Structure tab, Foundation panel, and Slab command. The corresponding properties were the layer thickness and the material: sand and gravel in the case of subgrade and sub-ballast/ballast layers, respectively. By way of example, the subgrade was modeled as a slab with dimensions of $12.0 \times 25.6 \times 0.45 \mathrm{~m}^{3}$. For the geotextile and geogrid components, the procedure was similar: the thickness was $5.4 \mathrm{~mm}$ (arbitrated value), and a new material, polypropylene, was created, with the appropriate thermal and mechanical properties, in addition to other product information (e.g., manufacturer and model).

Finally, the drainage elements were included in the 3D model, using the Systems tab, Plumbing $\mathcal{E}$ Piping panel, and Pipe command. Two identical pipes, $25.68 \mathrm{~m}$ long and $400 \mathrm{~mm}$ in diameter, were placed in a lateral position to the foundation layer.

Figure 6 represents the 3D model of the complete rail track including drainage: a perspective representation of the global 3D model (Figure 6a); a plan representation of the model (Figure 6b); and a representation of the cross-section of the total rail track structure and lateral drainage pipes (Figure 6c).

The interoperability between Civil $3 \mathrm{D} \AA$ and Revit ${ }^{\circledR}$ was also analyzed in terms of the terrain modeling. To import the terrain model, the Import CAD command was selected in the Import panel of the Insert tab. Then, the terrain surface was optimized using the Toposurface command in the Model Site panel, Massing $\mathcal{E}$ Site tab. In a new tab, the Create command from Import was selected. Figure 7 shows the final terrain model that was obtained: plan view (Figure 7a) and longitudinal profile (Figure 7b). 


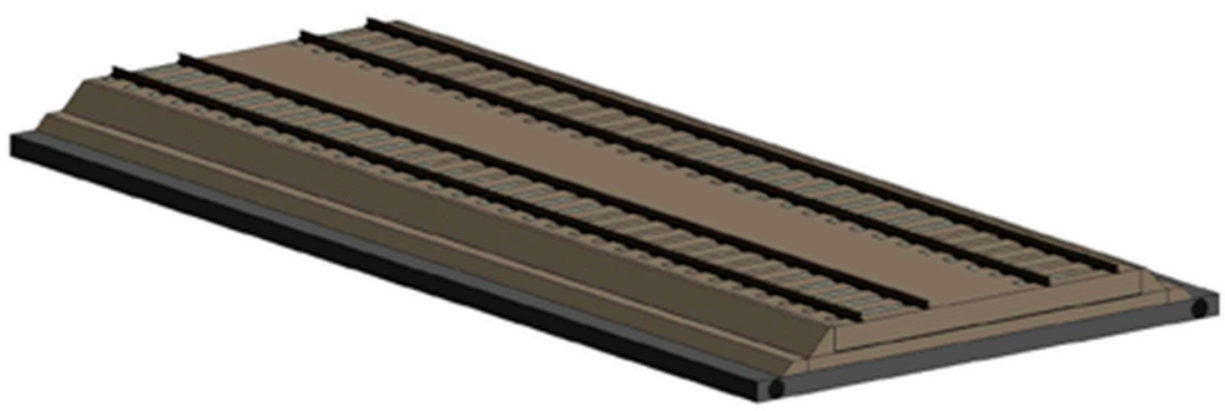

(a)

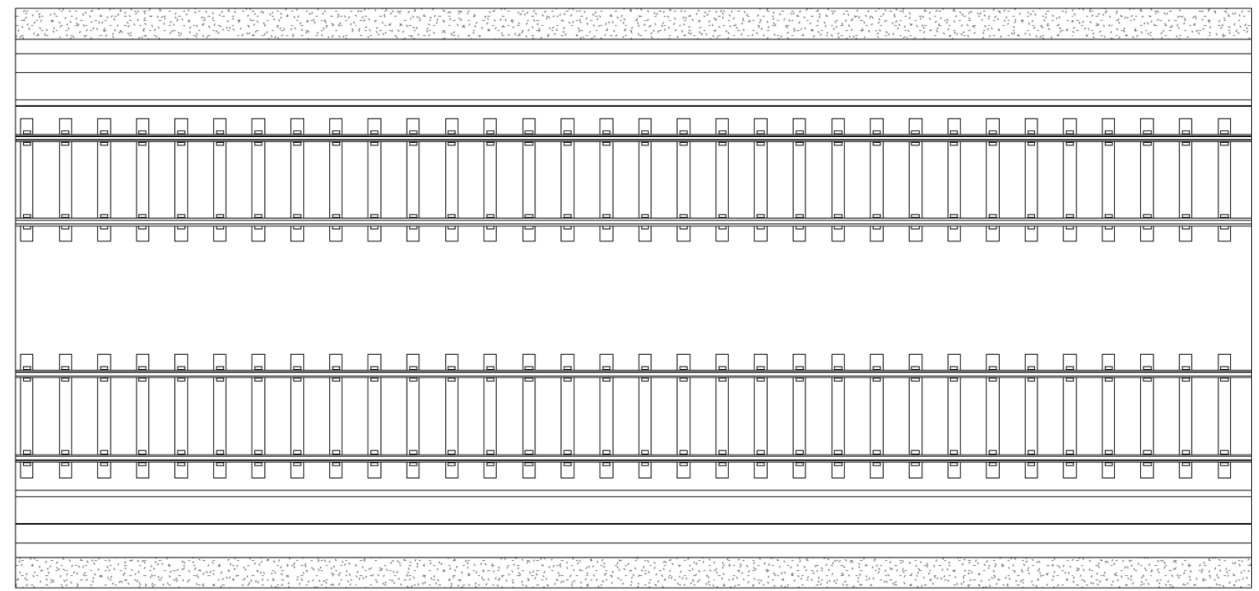

(b)

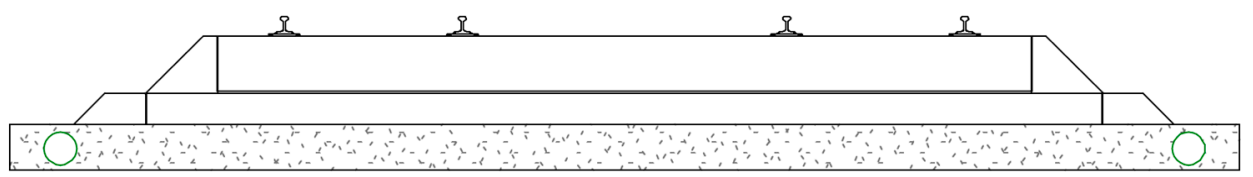

(c)

Figure 6. 3D model of the complete rail track including drainage created in Revit@: (a) perspective representation of the global 3D model; (b) plan representation of the model; and (c) the representation of the cross-section of the total rail track structure and lateral drainage pipes.

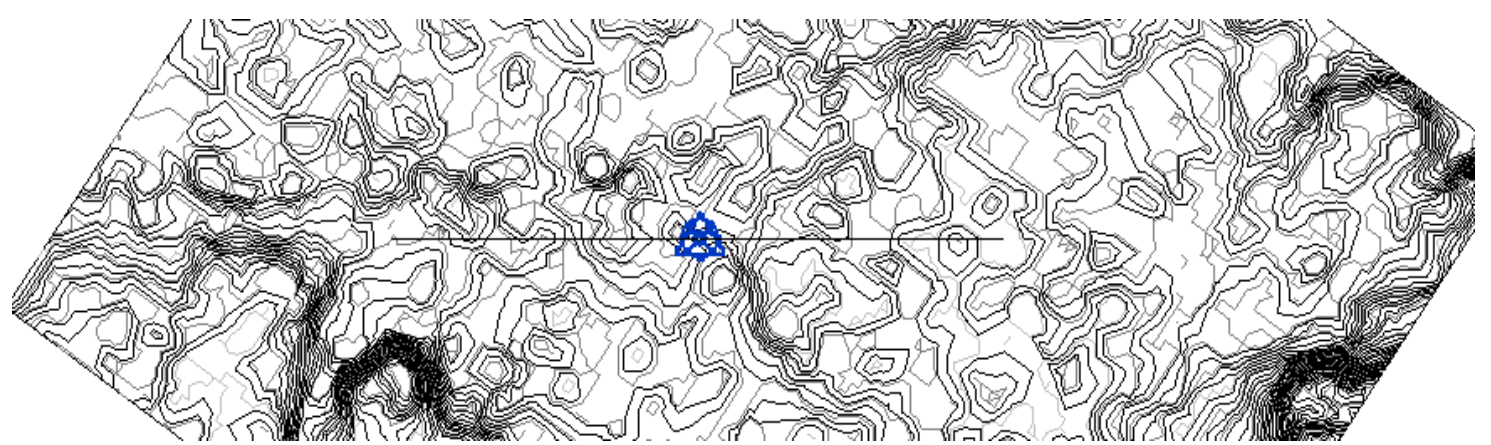

(a)

(b)

Figure 7. 3D model of the terrain created in Revit@: (a) plan view; and (b) longitudinal profile. 


\subsection{D Modeling}

The 4D BIM includes the time parameter that was applied in the construction planning and scheduling of the rail track rehabilitation. Navisworks ${ }^{\circledR}$ was the software used to create the $4 \mathrm{D}$ model. The construction planning and scheduling can be created directly in Navisworks ${ }^{\circledR}$ by means of Microsoft Project ${ }^{\circledR}$ import, or manually. Due to the restricted case study dimension, we opted for the manual process.

Seven sets were created to illustrate the different construction phases: existing rail track; replacement of track; removal of ballast; substructure; application of geotextile and geogrid; new ballast tamping; and final track tamping. Each set was created by selecting the components of the geometric model that correspond to that phase. Subsequently, construction tasks were added, including the planned beginning and end dates. In order to create the construction sequence, the TimeLiner command was used in the Home tab and Tools panel. The construction tasks were manually introduced into the schedule plan. Each of the various sets was allocated to its respective task.

A Gantt chart, concerning the rehabilitation of the rail track segment, was established directly within the Navisworks ${ }^{\circledR}$. Using the capacity of this BIM viewer, each task was linked to the correspondent construction component (ballast, substructure, geotextile, and geogrid). To accomplish this operation, the BIM model was created in a way that allowed the representation of each construction step. As such, it was possible to establish adequate links between geometric construction phases, representing the physical construction progress of the rail track rehabilitation, as illustrated in Figure 8.

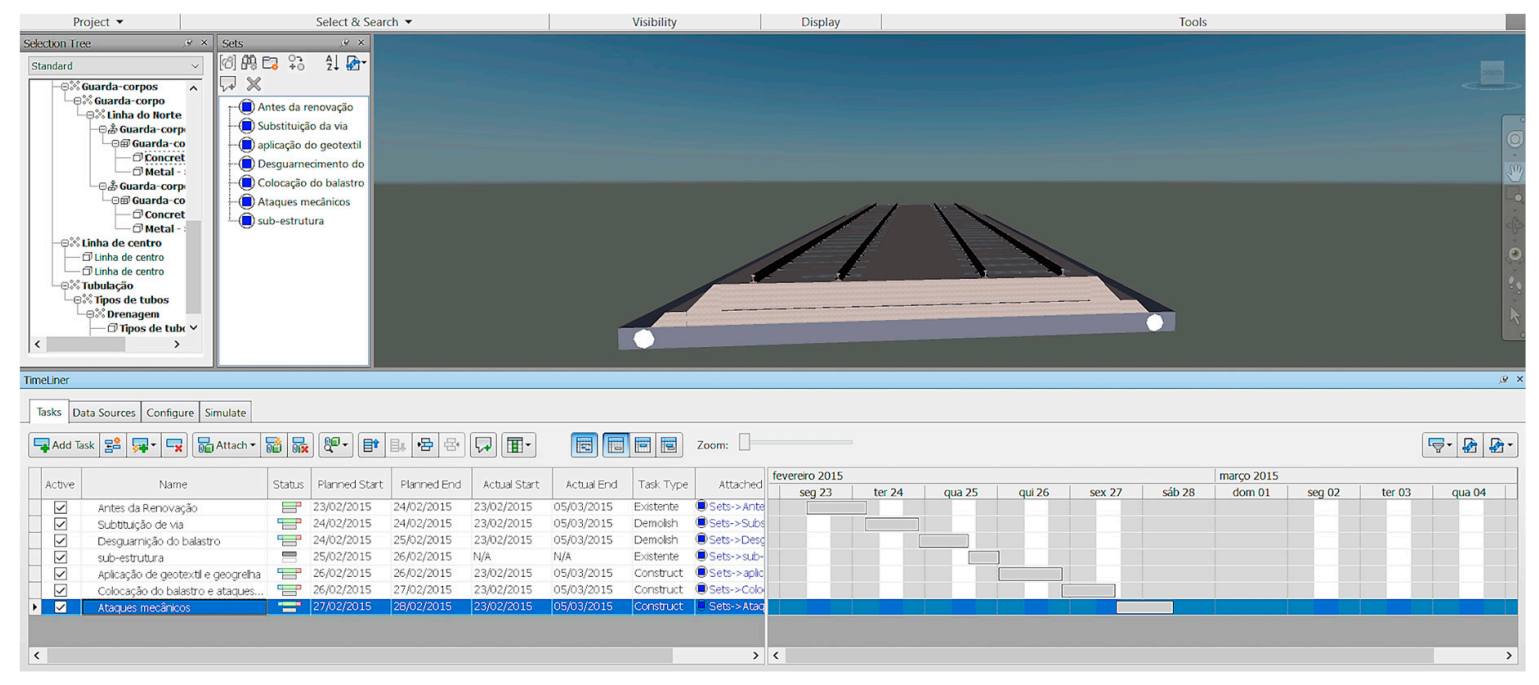

Figure 8. Interface of Navisworks®: generation of the 4D BIM model.

Figure 9 represents the construction phases: (a) existing rail track; (b) replacement of track; (c) removal of ballast; (d) substructure; $€$ application of geotextile and geogrid; (f) new ballast tamping; (g) final track tamping; and (h) rehabilitated rail track. The elements represented in green were the object of construction during the task, and the elements in red correspond to a removal or demolition process as part of the task. The two tasks, "existing rail track" and "substructure", were not real, but they were included with the aim of obtaining a more realistic simulation of the construction phases. The simulation of the different tasks planned for the rail track rehabilitation was obtained through the Simulate tab of the TimeLiner command. 


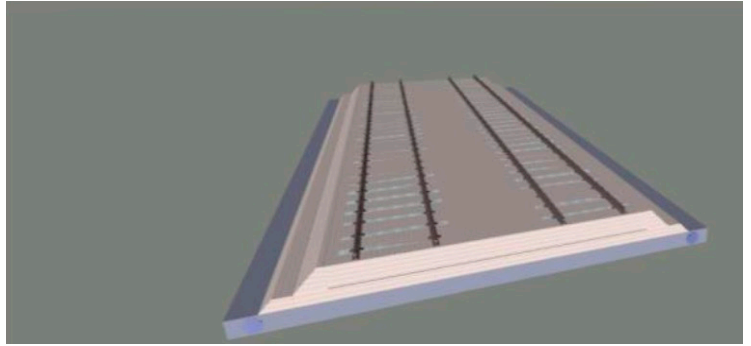

(a)

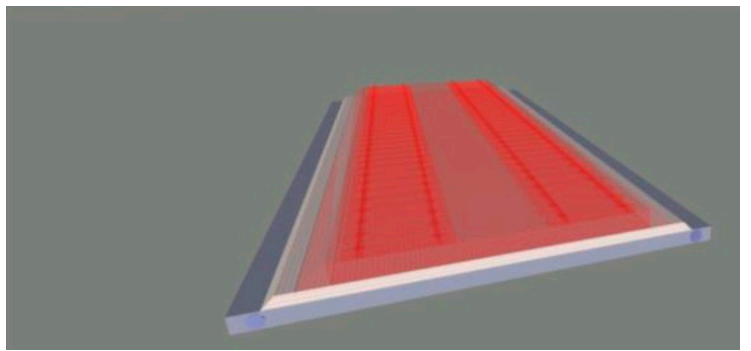

(c)

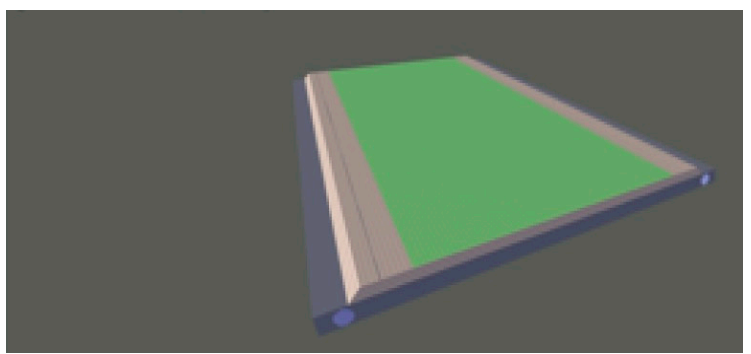

(e)

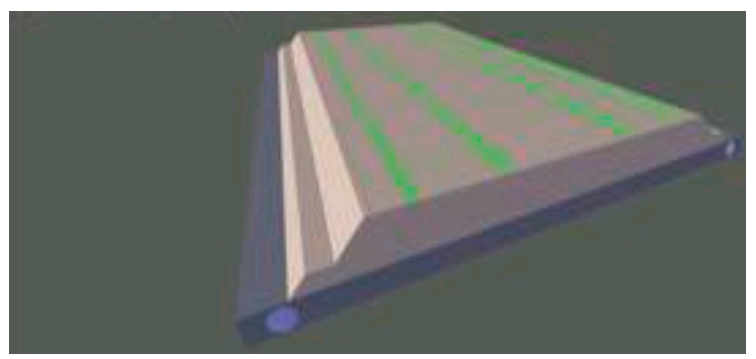

(g)

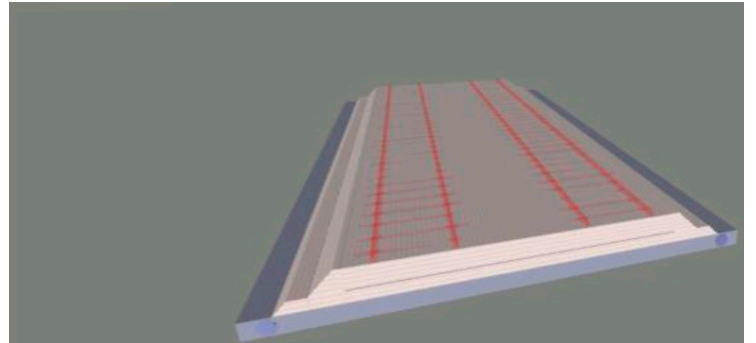

(b)

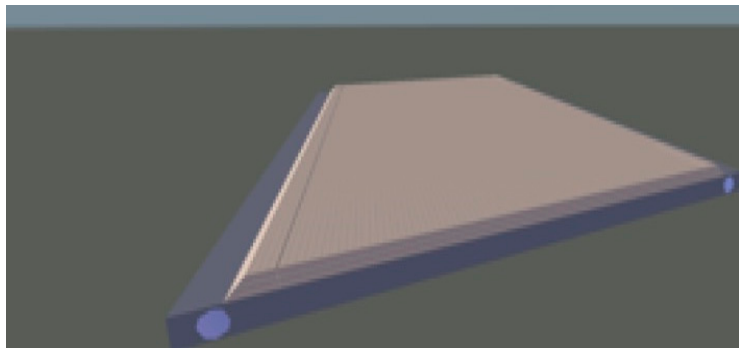

(d)

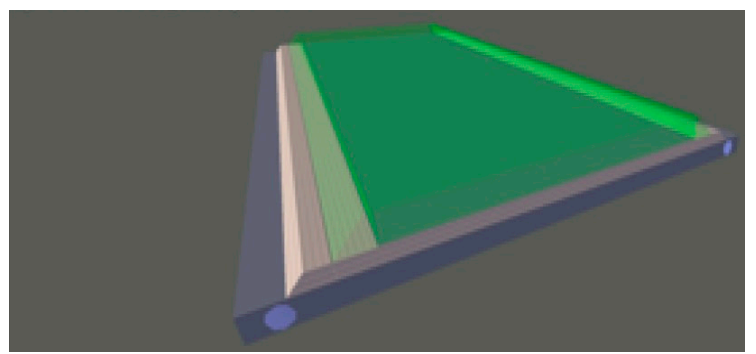

(f)

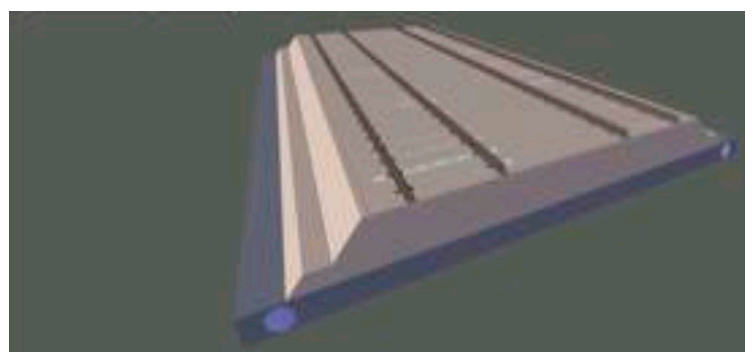

(h)

Figure 9. 4D model of the rail track construction in Navisworks ${ }^{\circledR}$ : (a) existing rail track; (b) replacement of track; (c) removal of ballast; (d) substructure; (e) application of geotextile and geogrid; (f) new ballast tamping; (g) final track tamping; and (h) rehabilitated rail track.

\section{Discussion}

Interoperability between systems plays a very important role in the BIM methodology. In Figure 3, the links between BIM software packages represent the interoperability analyzed in the case study. As already stated, difficulties were identified in terms of interoperability between some systems. In some cases, interoperability was even impossible. Taking into consideration that the programs used in the case study analyses were all from Autodesk, interoperability seemed to be guaranteed; but this could not be confirmed.

The creation of 3D models was always possible, although with certain limitations, because initially, the modeling would be carried out only in Civil 3D®. We later confirmed that this program was not the most suitable for the BIM methodology. Whilst Civil 3D® allowed for the creation of 3D representations quite correctly, the generated models were still based on lines and surfaces, as with 
the traditional AutoCAD 2D® software. This situation introduced interoperability issues, which have

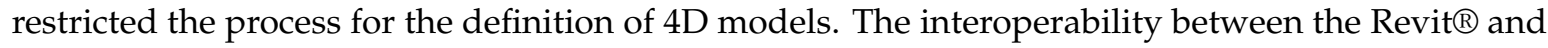
Navisworks ${ }^{\circledR}$ software packages facilitated the process of creating the tasks associated with the case study, with respect to the $4 \mathrm{D}$ modeling.

In BIM, it is possible to use tools that allow for extraction of a range of information from the models created. One of the most important components of a project is the drawing outputs, and it is a fundamental requirement that the designer can easily update them when changes and adjustments are made to the project. Figure 10 presents the graphic representation of the horizontal view (Figure 10a) and longitudinal profile (Figure 10b) of the rail track obtained from Civil 3D®. To obtain a drawing, a rectangle was first created, using the Create View Frames command in the Drawing Production panel, which was included in the Output tab. Then, to create the graphic outputs for alignment and the longitudinal profile, the Create sheets command was selected in the Drawing Production panel and Output tab.

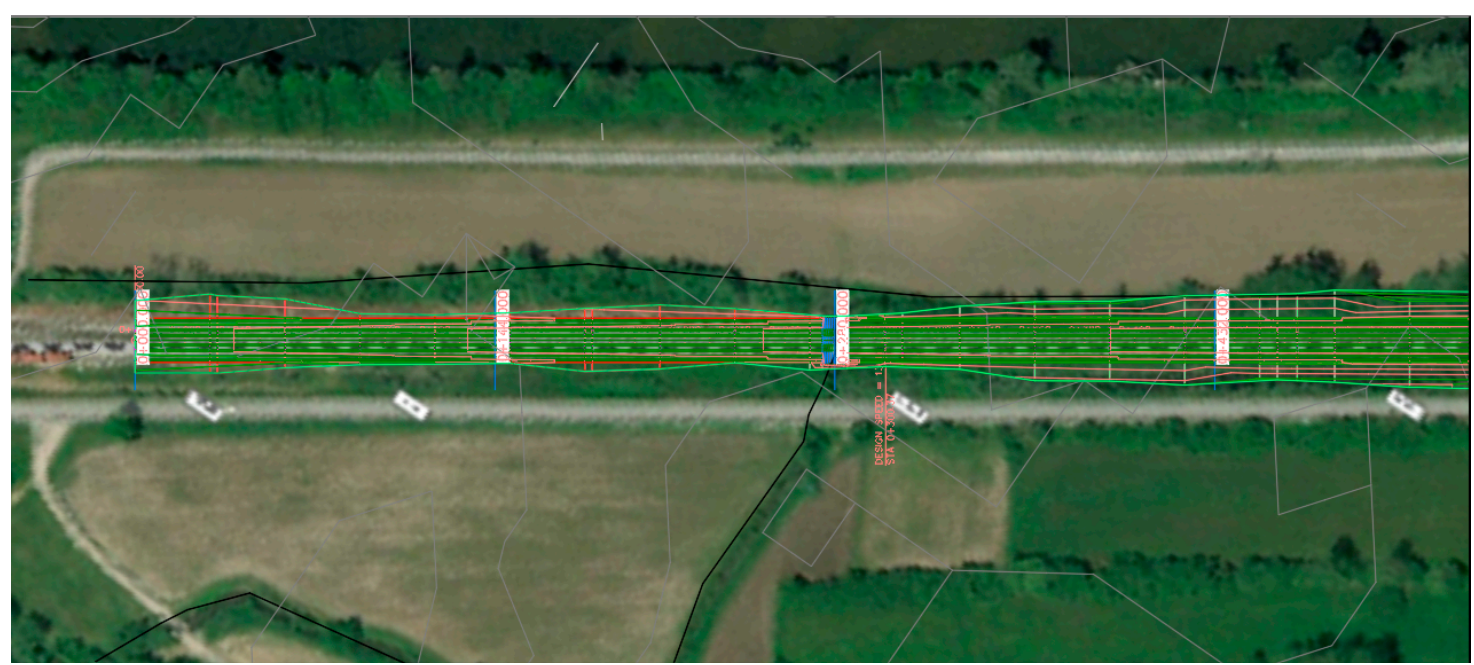

(a)

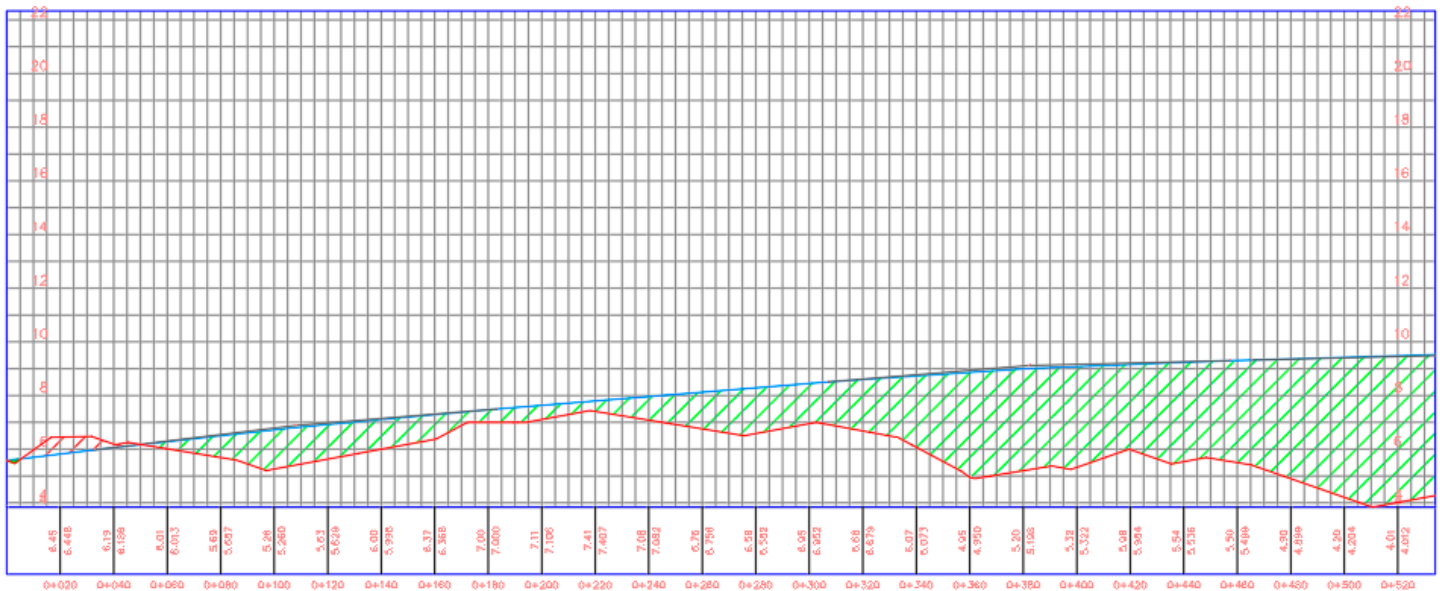

(b)

Figure 10. Geometry of the railway: (a) plan view; and (b) longitudinal profile.

However, drawings extracted from the 3D models were generally very incomplete, with respect to dimensions, annotations, and other informative text. Additional information, identical to the common information required in AutoCAD $2 D \AA$ software, was required.

The quantities of materials were a further type of information extracted from 3D models (Civil 3D® and Revit ${ }^{\circledR}$ ). This information was based on the measurement of the volumes of ballast and 
sub-ballast, the surface areas of geotextile and geogrid, and also the volumes for earthworks (landfills and excavations). It was likewise possible to extract information on rails, sleepers, and drainage elements. The sole limitation was the impossibility of quantifying the sleepers and rails because they were generated as a global parameter in $\operatorname{Revit}{ }^{\circledR}$, and not individually.

To ensure adequate and safe rail track behavior, monitoring of the quality of the construction and throughout the lifecycle of the railway infrastructure is crucial. Inspections are carried out to monitor the track condition. According to the EN 13848-1 standard, the main track geometric quality parameters are longitudinal leveling, transversal leveling, alignment, gauge, and twist. In Civil 3D®, it was only possible to control two geometric parameters: the gauge and transversal leveling. Further development is needed so that this very important functionality can be fully implemented in the BIM methodology.

Finally, the $4 \mathrm{D}$ model created in Navisworks ${ }^{\circledR}$ was very useful for producing flow and Gantt charts related to the planning and scheduling of activities.

The present work is focused, mainly, on the rehabilitation of a segment of railroad and not on obtaining information concerning the inspection or irregularities found in specific points along the track. However, as a complement to the present study, the inspection and control of the geometry is a perspective of great interest, to be developed in future work.

\section{Conclusions}

Major efforts are currently being made towards achieving a more generalized implementation of the BIM methodology in the domain of transport infrastructures, beyond specific components, e.g., tunnels, viaducts, and bridges. The aim of this paper was to contribute to this main goal through the demonstration of an application to a rail track rehabilitation case study.

The application of the BIM methodology consisted of three phases: (1) creation of the project model (3D); (2) planning and scheduling of the construction process (4D); and (3) extraction of diverse model information. The objectives of these phases were achieved in general using different software packages. The Civil 3D® and Revit ${ }^{\circledR}$ packages proved suitable for 3D modeling, including the rail track, drainage, and catenary systems. Interoperability between these tools was analyzed. However, the total integration into Revit ${ }^{\circ}$ of the 3D model created by Civil 3D ${ }^{\circledR}$ was unsuccessful because most of the elements were not recognized. Based on the integration of two rail track component families existing in the BIM Library, a new Revit ${ }^{\circledR}$ family was created in order to represent the complete rail track. The Navisworks ${ }^{\circledR}$ program was used to create the $4 \mathrm{D}$ model. Seven sets were created to illustrate the different construction phases: existing rail track; replacement of track; removal of ballast; substructure; application of geotextile and geogrid; new ballast tamping; and final track tamping. It was also possible to establishing adequate links between geometric constructions, representing the physical construction progress. The interoperability between the Revit ${ }^{\circledR}$ and Navisworks ${ }^{\circledR}$ packages facilitated the process of creating the tasks associated with the case study, regarding the 4D modeling.

BIM tools allowed for extraction of diverse information from the created models: planning and scheduling; quantities of materials; graphic outputs; and track geometry quality. This information is useful for the design, construction, and exploration of transport infrastructure.

In the domain of transport infrastructure systems, the railways present specificities and complexity that confer to BIM implementation a greater interest and importance. The highest safety exigencies of the railway operation (e.g., high speed train) require more frequent monitoring and maintenance operations. Additionally, the complexity of railway components and systems (infrastructure and vehicles) requires better tools for data analysis and processing. In this sense, BIM will be a useful methodology with enormous technical, economic, and environmental advantages along the railway infrastructure lifecycle. The application of BIM-based tools to the case study described in this paper has demonstrated that, in spite of certain difficulties and limitations, the methodology has great potential and should be explored further. 
For the future development of BIM implementation in the domain of transport infrastructures, advancement of the development of families specific to transport infrastructures is recommended, particularly in Revit ${ }^{\circ}$, so that projects can be modeled more easily and also be more complete and realistic. Another important recommendation is the integration in the BIM methodology of an adequate track inspection system that includes all the usual geometric parameters, so that maintenance planning associated with quality control inspection tests can be integrated. It is also believed that the reported issues on the interoperability between BIM tools will be overcome in the short term, taking into account the current and foreseeable evolution of the digital systems.

Author Contributions: Conceptualization, J.N. and Z.S.; investigation, M.V.; methodology, M.V.; supervision, J.N. and Z.S.; validation, J.N. and Z.S.; writing, original draft, J.N.; writing, review and editing, J.N. and Z.S.

Funding: This research received no external funding.

Acknowledgments: The authors acknowledge the Portuguese Railway Authority ("Infraestruturas de Portugal, $\mathrm{SA}^{\prime \prime}$ ) for the permission to use and disseminate the project information related to the case study.

Conflicts of Interest: The authors declare no conflict of interest.

\section{References}

1. Bryde, D.; Broquetas, M.; Volm, J.M. The project benefits of Building Information Modelling (BIM). Int. J. Project Manag. 2013, 31, 971-980. [CrossRef]

2. Davies, R.; Crespin-Mazet, F.; Linne, A.; Pardo, C.; Ingemannson Havenvid, M.; Harty, C.; Ivory, C.; Salle, R. BIM in Europe: Innovation networks in the construction sectors of Sweden, France and the UK. In Proceedings of the 31st Annual ARCOM Conference, Lincoln, UK, 7-9 September 2015; pp. 1135-1144.

3. Li, J.; Li, N.; Peng, J.; Cui, H.; Wu, Z. A review of currently applied building information modeling tools of constructions in China. J. Clean. Prod. 2018, 201, 358-368. [CrossRef]

4. López, F.J.; Lerones, P.M.; Llamas, J.; Gómes-García-Bermejo, J.; Zalama, E. A Review of Heritage Building Information Modeling (H-BIM). Multimodal Technol. Interact. 2018, 2, 21. [CrossRef]

5. Ma, Z.; Liu, S. A review of 3D reconstruction techniques in civil engineering and their applications. Adv. Eng. Inform. 2018, 37, 163-174. [CrossRef]

6. Pezeshki, Z.; Ivari, S.A.S. Applications of BIM: A brief review and future outline. Arch. Comput. Methods Eng. 2018, 25, 273-312. [CrossRef]

7. Bradley, A.; Li, H.; Lark, R.; Dunn, S. BIM for infrastructure: An overall review and constructor perspective. Autom. Constr. 2016, 71, 139-152. [CrossRef]

8. Campestrini, F.; Garrido, M.; Scheer, S.; Freitas, M. Entendendo BIM; Campestrini, F., Ed.; Universidade Federal do Paraná: Curitiba, Brazil, 2015. Available online: http:/ /www.gpsustentavel.ufba.br/documentos / livro_entendendo_bim.pdf (accessed on 26 December 2018).

9. Bensalah, M.; Elouadi, A.; Mharzi, H. Integrating BIM in railway projects: Review \& perspectives for Morocco \& Mena. Int. J. Recent Sci. Res. 2018, 9, 23398-23403. [CrossRef]

10. Bensalah, M.; Elouadi, A.; Mharzi, H. BIM integration to railway-Literature \& experiences critical review. In Proceedings of the 11th International Colloquium of Logistics and Supply Chain Management LOGISTIQUA 2018, Tangier, Morocco, 26-27 April 2018; Volume 11.

11. Costin, A.; Adibfar, A.; Hu, H.; Chen, S.S. Building Information Modeling (BIM) for transportation infrastructure-Literature review, applications, challenges, and recommendations. Autom. Constr. 2018, 94, 257-281. [CrossRef]

12. Zak, J.; Macadam, H. Utilization of building information modeling in infrastructure's design and construction. IOP Conf. Ser. Mater. Sci. Eng. 2017, 236, 012108. [CrossRef]

13. Blanco, F.G.B.; Chen, H. The implementation of Building Information Modelling in the United Kingdom by the Transport Industry. Procedia Soc. Behav. Sci. 2014, 138, 510520. [CrossRef]

14. Fanning, B. Impacts and Benefits of Implementing BIM on Bridge and Infrastructure Projects. Master's Thesis, Colorado State University, Fort Collins, CO, USA, 2014.

15. Noor, B.A.; Yi, S. Review of BIM literature in construction industry and transportation: Meta-analysis. Constr. Innov. 2018, 18, 433-452. [CrossRef]

16. Suchocki, M. The BIM-for-rail opportunity. WIT Trans. Built Environ. 2017, 169, 37-44. [CrossRef] 
17. Huang, S.-F.; Chen, C.-S.; Dzeng, R.-J. Design of Track Alignment Using Building Information Modeling. J. Transp. Eng. 2011, 137. [CrossRef]

18. Norberg, A. Implementing Building Information Modeling within the Railway Sector. Master's Thesis, Chalmers University of Technology, Göteborg, Sweden, 2012.

19. Lee, S.-H.; Park, S.I.; Park, J.; Seo, K.-W. Open BIM-Based Information Modeling of railway bridges and its application concept. Comput. Civil Build. Eng. 2014. [CrossRef]

20. Sanchez, A.X.; Kraatz, J.A.; Hampson, K.D.; Loganathan, S. BIM for sustainable whole-of-life transport infrastructure asset management. In Proceedings of the Sustainability in Public Works Conference, Tweed Heads, Australia, 27-29 July 2014.

21. Smith, S. Building information modelling-Moving Crossrail, UK, forward. Proc. Inst. Civil Eng. Manag. Procure. Law 2014, 167, 141-151. [CrossRef]

22. Porto, M.F.; Falcão, P.C.; Franco, J.R.Q.; Baracho Porto, R.M.A.; Nunes, N.T.R. Automatic Analysis of Standards in Rail Projects. J. Syst. Cybern. Inform. 2015, 13, 39-44.

23. Shr, J.-F.; Liu, L.-S. Application of BIM (Building Information Modeling) and GIS (Geographic Information System) to railway maintenance works in Taiwan. J. Traffic Transp. Eng. 2016, 4, 18-22. [CrossRef]

24. Augele, V. Comparative Analysis of Building Information Modelling (BIM) and RailTopoModel/railML in View of Their Application to Operationally Relevant Railway Infrastructure; Project Paper in the Field of Intelligent Transportation Systems; Technical University od Dresden: Dresden, Germany, 2017.

25. Kurwi, S.; Demian, P.; Hassan, T.M. Integrating BIM and GIS in railway projects: A critical review. In Proceedings of the 33rd Annual ARCOM Conference, Cambridge, UK, 4-6 September 2017; pp. 45-53.

26. Transport and Main Roads. Building Information Modelling (BIM) for Transport and Main Roads; A Guide to Enabling BIM on Road Infrastructure Projects; Department of Transport and Main Roads: State of Queensland, Fortitude Valley, Australia, 2017.

27. Nuttens, T.; De Breuck, V.; Cattor, R.; Decock, K.; Hemeryk, I. Using Bim models for the design of large rail infrastructure projects: Key factors for a successful implementation. Int. J. Sustain. Dev. Plan. 2018, 13, 73-83. [CrossRef]

28. Tveit, M.; Gjerde, K. Using building information modelling for planning a highspeed rail project in Norway. Proc. Inst. Civil Eng. Civil Eng. 2018, 171, 121-128. [CrossRef]

29. Leone, M.; D’Andrea, A.; Loprencipe, G.; Malavasi, G.; Bernardini, L. Building information modeling (BIM): Prospects for the development of railway infrastructure industry. In Proceedings of the AIIT, International Congress on Transport Infrastructure and Systems, Rome, Italy, 10-12 April 2017; pp. 547-553. [CrossRef]

30. Chong, H.Y.; Lopez, R.; Wang, J.; Wang, X.; Zhao, Z. Comparative analysis on the adoption and use of BIM in road infrastructure projects. J. Constr. Eng. Manag. 2016, 32, 1-13. [CrossRef]

31. Bensalah, M.; Elouadi, A.; Mharzi, H. Optimization of cost of a tram through the integration of BIM: A theoretical analysis. Int. J. Mech. Prod. Eng. (IJMPE) 2017, 5, 138-142.

32. Shin, M.H.; Lee, H.K.; Kim, H.Y. Benefit-Cost Analysis of Building Information Modeling (BIM) in a railway site. Sustainability 2018, 10, 4303. [CrossRef]

33. Kenley, R.; Toby, H.; Ali, B. BIM interoperability limitations: Australian and Malaysian rail projects. In Proceedings of the MATEC Web of Conferences, 4th International Building Control Conference 2016 (IBCC 2016), Kuala Lumpur, Malaysia, 7-8 March 2016; Volume 66. [CrossRef]

34. CRBIM. Research of Railway BIM Data Standard. Draft version for buildingSMART; China Railway BIM Alliance: Beijing, China, 2015.

35. Neves, J.; Lima, H.; Rodrigues, F. The use of geosynthetics in the construction and rehabilitation of transportation infrastructures in Portugal. Workshop 1: Geosynthetics in Transportation Geotechnics. In Proceedings of the 3rd International Conference on Transportation Geotechnics, Guimarães, Portugal, 4 September 2016; pp. 39-42, ISBN 978-972-8692-98-8. [CrossRef]

36. Vilela, M. BIM Implementation to Transport Infrastructure. Master's Thesis, Instituto Superior Técnico, University of Lisbon, Lisbon, Portugal, 2018. (In Portuguese)

37. Queirós, B. Application of geogrids in rail renovation works-Case study. In Proceedings of the 1st Seminar on Transportation Geotechnics, Lisbon, Portugal, 12-13 October 2017. [CrossRef]

(C) 2019 by the authors. Licensee MDPI, Basel, Switzerland. This article is an open access article distributed under the terms and conditions of the Creative Commons Attribution (CC BY) license (http:/ / creativecommons.org/licenses/by/4.0/). 